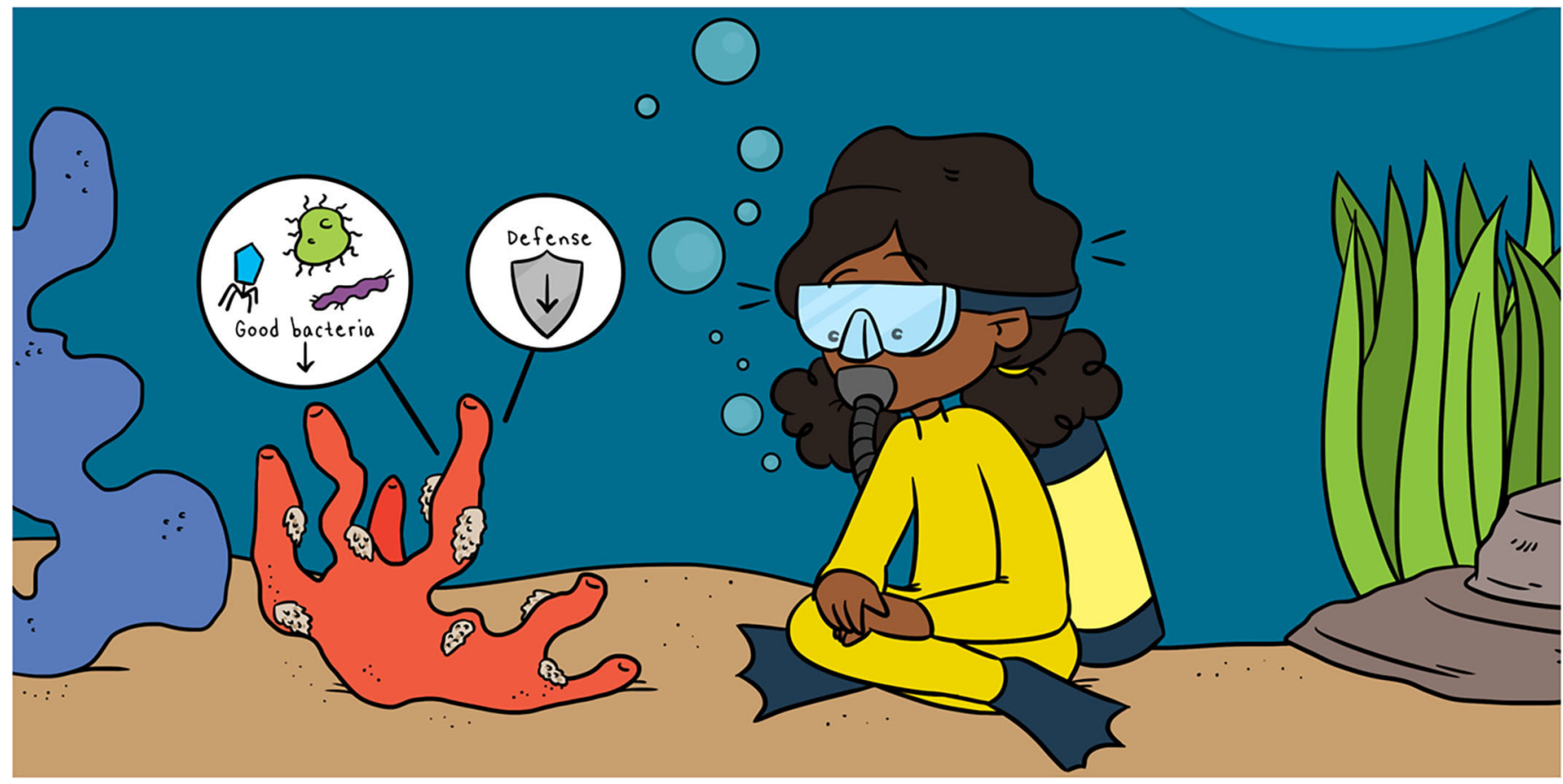

\title{
THE HUNGRY SNAIL, THE FRAGILE CORAL, AND THE FRIENDLY MICROBE
}

Yvan Bettare ${ }^{1 *}$, Elyse Boudin ${ }^{1}$, Sébastien Halary ${ }^{2}$, Jean-Christophe Auguet ${ }^{1}$, Jean Péronnin ${ }^{3}$, Thierry Bouvier ${ }^{1}$, Emma Rochelle-Newall ${ }^{4}$, Van Ngoc Bui ${ }^{5}$ and Christelle Desnues ${ }^{6}$

${ }^{1}$ UMR MARBEC IRD-CNRS-IFREMER-Université Montpellier, Montpellier, France

2 UMR MCAM, Muséum National d'Histoire Naturelle, CNRS, Paris, France

${ }^{3}$ Vocational School Henri Sainte Claire Deville, Issoire, France

${ }^{4}$ Institute of Ecology and Environmental Sciences of Paris (iEES-Paris), Sorbonne Université, University Paris Est Creteil, IRD, CNRS, INRA, Paris, France

${ }^{5}$ Institute of Biotechnology of Hanoi (IBT), Vietnam Academy of Science and Technology (VAST), Hanoi, Vietnam ${ }^{6} \mathrm{MIO}$, Aix-Marseille Université, Université de Toulon, CNRS, IRD, Marseille, France

YOUNG REVIEWERS:

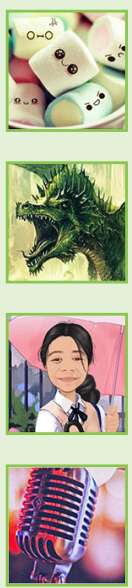

ADITRI

AGE: 12

ANSHUL

AGE: 9

LUVENA

AGE: 11

PRANATEE

AGE: 12
Off the coast of Vietnam, two recent events seem to have contributed to the death of coral reefs: the rapid invasion of a small marine snail called Drupella, and the emergence of a disease that spreads over corals. We decided to investigate whether there is a link between the corals, the snails, and the disease. We analyzed the mucus covering the surface of corals, both in healthy corals and those infested by Drupella snails. Mucus produced by corals is usually full of helpful microbes, protecting the corals from harmful microbes that can make them ill or kill them. Our analyses showed that, when Drupella eats corals, the snail also removes one of the corals' primary defenses by eliminating most of the tiny protectors in their mucus. This allows harmful microbes to cause additional damage to the corals. 
CORAL DISEASE

Several diseases can affect corals and cause whitening of their surfaces or the formation of white, black, or brown bands on the corals. Coral diseases are mostly caused by bacteria, viruses, or small fungi, and can sometimes lead to coral death.

\section{MICROBE}

An organism so small that it cannot be seen with the naked eye. Microbes, which include bacteria and viruses, are the most abundant organisms on earth and are found everywhere-in the air, in the water, and associated with all living organisms.

\section{IMMUNE SYSTEM}

The bodily system that recognizes unfriendly microbes and defends the organism against them

MUCUS

The viscous layer produced at the skin surface of most marine animals. It contains a large number of useful microbes involved in the protection of the animal against the surrounding microbial invaders.

\section{NO ESCAPE FOR CORALS}

To protect themselves from attacks by predators, animals like gazelles, rabbits, or mice can run away. For these animals, running is possible because they are mobile. However, other animals are either unable to move or can only move very slowly, over small distances. This is the case for corals. Corals are minuscule animals that live together in rock structures that they build. The rock structures form the coral reefs known for their beauty and for providing shelter for thousands of marine species, including fish, sponges, crustacean, and worms. Sadly, coral reefs are also known for their fragility and the threats that plague them: warming water, predation, hurricanes, damage from human hands and diving fins, and pollution, to name but a few. In addition to their inability to run away from threats, corals naturally grow very slowly-just a few millimeters per year. Today, one-third of coral species are endangered and may disappear in the near future.

\section{THE SNAIL ATTACK}

Some fish and starfish species are famous for feeding on corals, but recently a small marine snail called Drupella, native to the Indian and Pacific oceans, was also discovered to be an active coral predator. In some parts of the world, these slow-moving killers are increasing in number and their attacks sometimes kill the corals.

Our research team went to the Bay of Nha Trang in Vietnam. There, the corals are suffering from the growing population of Drupella. In small numbers, this snail does not do much damage, but in recent years the snail population has greatly increased. Corals colonized by snails show two interesting characteristics. First, the corals are left totally white and lifeless after the snails are done with them. Second, traces of coral disease are also visible on the parts of the corals the snails have not yet touched (Figure 1). The aim of our research was to learn more about the links between the snails and the diseases that devastate the corals in Nha Trang. We wanted to see whether Drupella caused disease or whether the corals were already sick before the snails' arrival. So, we decided to dive in to take a closer look at the corals.

\section{CORAL MUCUS, A PROTECTIVE LAYER FULL OF HELPFUL MICROBES}

Our first step was to understand the origin of the coral disease. Since corals are unable to move, they are particularly vulnerable to attack by predators. However, they do have defenses against microbial invaders, and not all microbes are dangerous for corals. On the contrary, some microbes help corals stay healthy and are considered to be a component of the corals' immune system! It is in the corals' mucus 
Figure 1

(A) The Bay of Nha Trang in Vietnam, where our study took place. (B) Drupella eating corals: some parts of the corals are already white, corresponding to the grazed surface. The close-up shows different individuals of Drupella rugosa (๑) ConserveMarine, CC BY-SA 4.0).

\section{VIRUSES}

The smallest microorganisms on earth (ten times smaller than bacteria). Viruses cannot reproduce by themselves. For this, they have to find a host (which could be bacteria, a plant, an animal, a human being...), get inside the host, multiply, and usually get back out. Like bacteria, they are not always harmful and responsible for diseases. On the contrary, most of them actually protect their host against dangerous bacteria!

\section{DNA SEQUENCING}

Powerful machine, which allows deciphering the genetic information (DNA) contained in each cell.

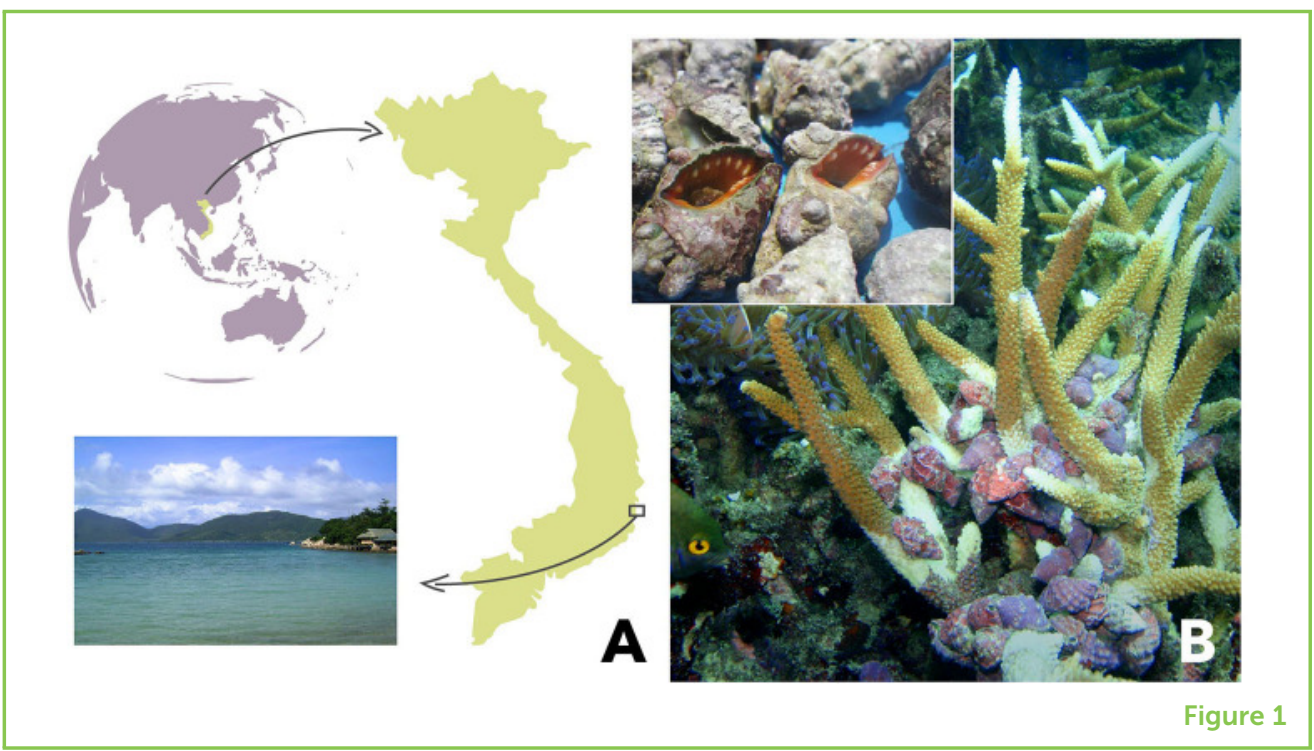

layer that the battle between helpful and harmful microbes plays out. Mucus is a thick, sticky substance that completely covers corals and is produced by the coral itself. This mucus layer contains many helpful microbes that act like soldiers, eliminating any other harmful microscopic intruder that tries to make the corals sick. In our study, we wanted to understand how these tiny soldiers would react during a snail attack. So, we collected the mucus from different parts of corals with and without Drupella, to compare them.

\section{EXAMINING MICROBES IN THE CORAL MUCUS}

Bacteria and viruses are incredibly small. To give you a sense of scale, bacteria are 100 times smaller than the width of a single hair and viruses are more than 10 times smaller than bacteria! It is therefore impossible to see such small organisms with the naked eye. To detect and identify them, we use DNA sequencing. DNA is found in the cells of all living organisms. It contains the genetic code of the organism and determines all the features of that organism. Imagine an instruction manual with an alphabet of only 4 different letters! The difference between the instruction manual of a human and that of a goldfish is just a matter of the order of some of those letters. Each species' instruction manual (their DNA) is unique. We extracted as much DNA as possible from the coral mucus, to identify all the microbes living there. Then we searched a database in which the DNA codes of all known living species are referenced (Figure 2), to find the identities of the species we discovered in the coral mucus.

\section{SNAILS DAMAGE CORAL MUCUS}

We found that the mucus of corals colonized by Drupella was different from the mucus of healthy corals. The bacteria and viruses found in 


\section{Figure 2}

Identifying microbes living in coral mucus. (1) Mucus is taken from healthy and snail-eaten corals. (2) Mucus is filtered to collect all the microbes. (3) DNA is extracted from the microbes. (4) The microbial DNA is placed in small boxes. (5) A sequencing machine reads and determines the sequences of the DNA in the samples. (6) A computer analyses the data and compares it to a database with the DNA sequences of all known microbes. (7)

This tells us which microbes, both helpful and harmful, are present in the mucus (CElyse Boudin).

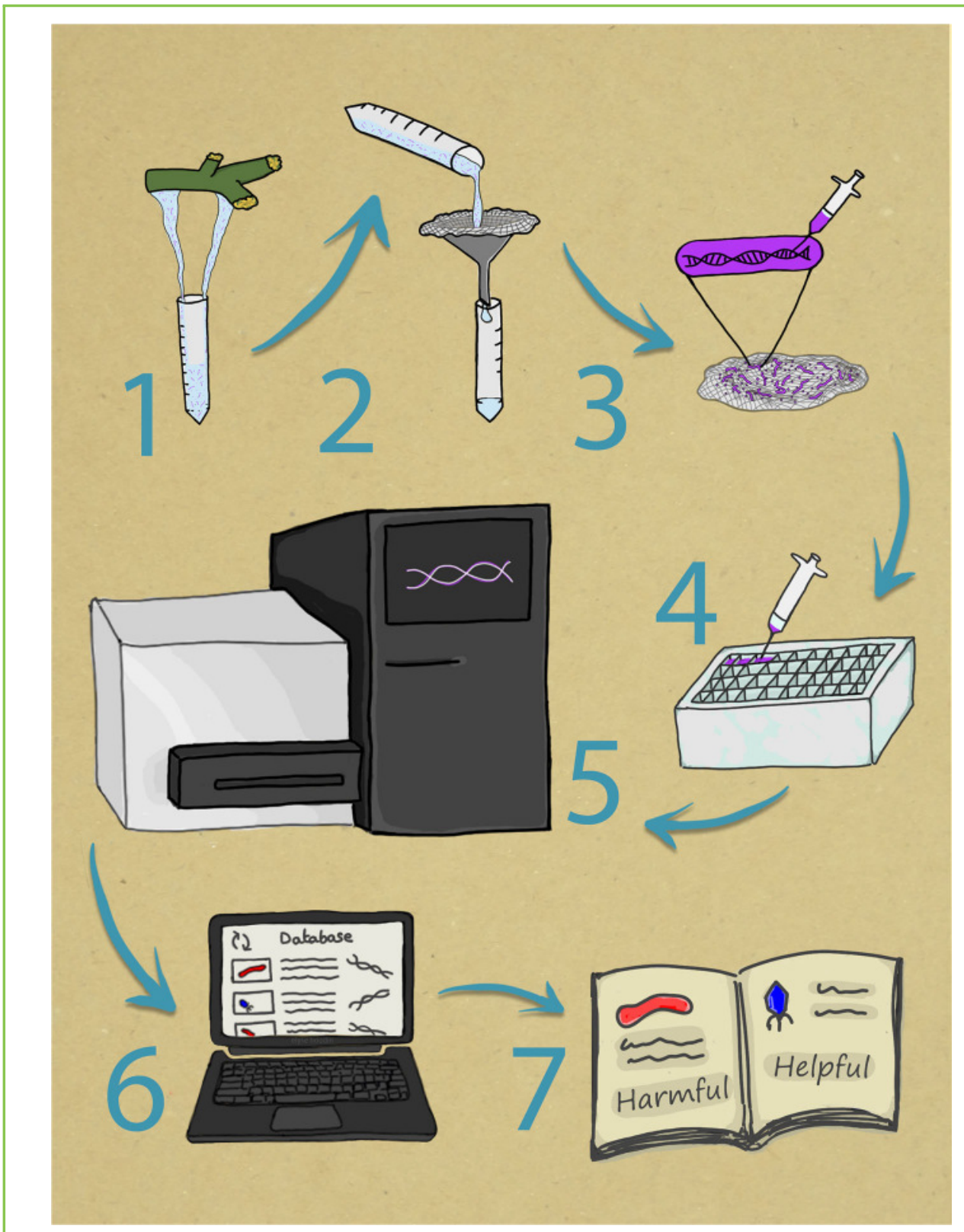

Figure 2

the snail-colonized coral mucus were different than those found in healthy corals that were spared by the snails, and there were many more of them. Sadly, many of the helpful microbes were also replaced by harmful microbes that are typically responsible for coral diseases (Figure 3). Why are the dangerous microbes growing on the corals that were attacked by snails? Are the snails responsible for this? We believe that the snails, while eating the corals, also seriously damage the corals' mucus layer and the helpful microbes living in it. If these helpful microbes are no longer able to protect the corals against harmful microbes, then the corals can come under the control of those harmful microbes and become sick. 
Figure 3

Comparison of corals with and without Drupella. (A) The magnifying glass shows us that healthy corals host helpful microbes (blue) in their mucus, which protect them against harmful ones (red). (B) When the mucus layer is damaged by Drupella more harmful microbes grow, which results in the development of coral diseases (@) Jean Péronnin).

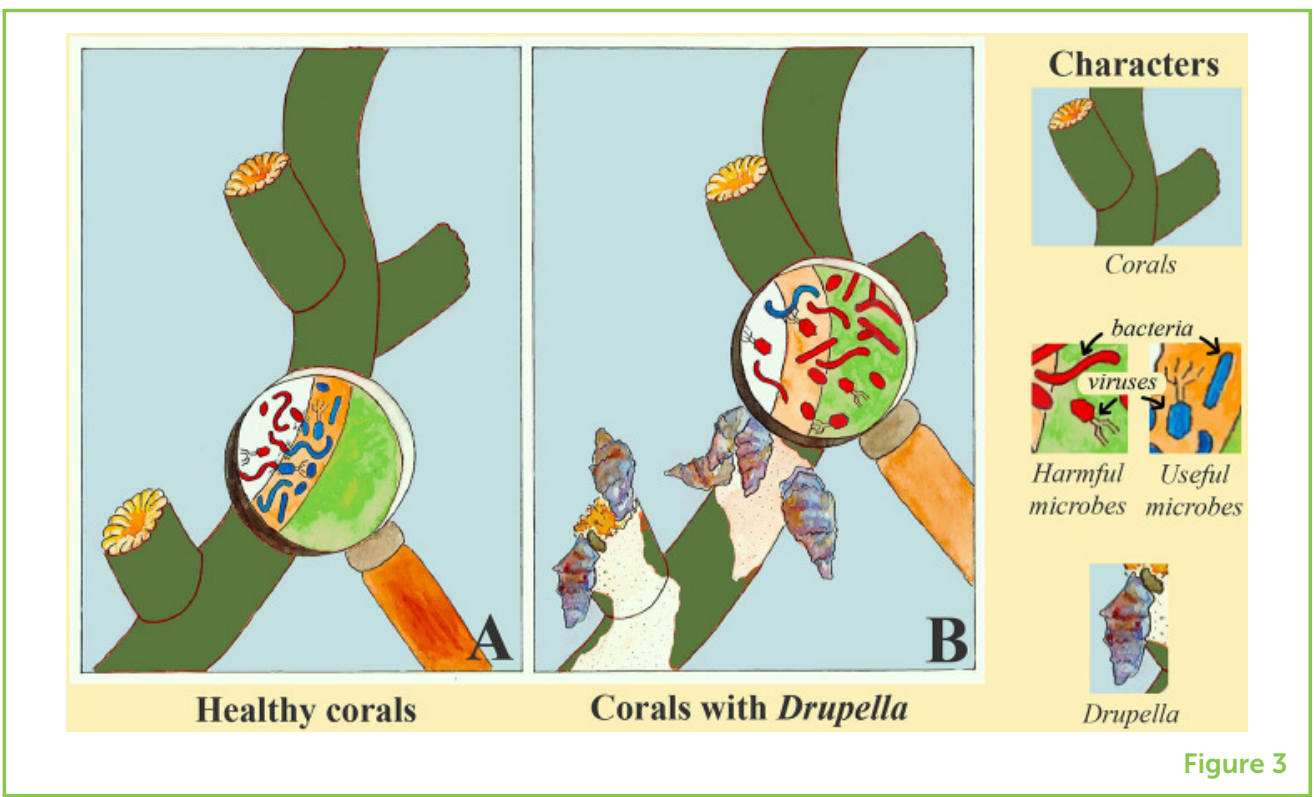

\section{MORAL OF THE STORY}

The "hungry" snail Drupella is naturally present in the seas of Southeast Asia and its population has increased enormously in recent years. The reason for this increase is believed to be overfishing, because the larvae of Drupella snails are normally eaten by fish. Overfishing reduces the number of fish, meaning that more Drupella larvae survive and become adults. Adult Drupella have hard shells and are totally inedible, so they can safely grow and multiply. So, you can clearly see that overfishing has consequences on coral health! We found that not only do the snails scrape the surface of corals and damage them, but snail attack also makes fragile corals even more vulnerable, by providing a path for the invasion of harmful bacteria and viruses.

Finally, our original study [1] shows the importance of both the coral mucus and the helpful bacteria living there that serve as part of the corals' immune system. Microscopic organisms are being studied by more and more groups, as they are found everywhere in marine animals: in their guts, on their skin, and even in their brains! These helpful microbes have many positive effects on their hosts. This also holds true for humans. The microbes that live on and inside our bodies play important roles in our health, our food digestion, and even in our behavior. Those microbes seem to act as an extremely organized community. However, helpful microbes are so abundant and diverse that we still do not know what they all do. Therefore, we need to continue to research the roles of helpful microbes in all species, since they could reveal other hidden secrets that would help us protect the health of all organisms, from fragile corals to humans. 


\section{ORIGINAL SOURCE ARTICLE}

Bettarel, Y., Halary, S., Auguet, J. C., Mai, C. T., Bui, V. N., Bouvier, T., et al. 2018. Corallivory and the microbial debacle in two branching scleratinians. ISME J. 12:1109-26. doi: 10.1038/s41396-017-0033-5

\section{REFERENCES}

1. Bettarel, Y., Halary, S., Auguet, J. C., Mai, C. T., Bui, V. N., Bouvier, T., et al. 2018. Corallivory and the microbial debacle in two branching scleratinians. ISME J. 12:1109-26. doi: 10.1038/s41396-017-0033-5

SUBMITTED: 18 June 2020; ACCEPTED: 02 July 2021; PUBLISHED ONLINE: 04 August 2021.

EDITED BY: Nathan M. Good, University of California, Berkeley, United States

CITATION: Bettarel Y, Boudin E, Halary S, Auguet J, Péronnin J, Bouvier T, Rochelle-Newall E, Bui VN and Desnues C (2021) The Hungry Snail, the Fragile Coral, and the Friendly Microbe. Front. Young Minds 9:573856. doi: 10.3389/frym. 2021.573856

CONFLICT OF INTEREST: The authors declare that the research was conducted in the absence of any commercial or financial relationships that could be construed as a potential conflict of interest.

COPYRIGHT (c) 2021 Bettarel, Boudin, Halary, Auguet, Péronnin, Bouvier, Rochelle-Newall, Bui and Desnues. This is an open-access article distributed under the terms of the Creative Commons Attribution License (CC BY). The use, distribution or reproduction in other forums is permitted, provided the original author(s) and the copyright owner(s) are credited and that the original publication in this journal is cited, in accordance with accepted academic practice. No use, distribution or reproduction is permitted which does not comply with these terms.

\section{YOUNG REVIEWERS}

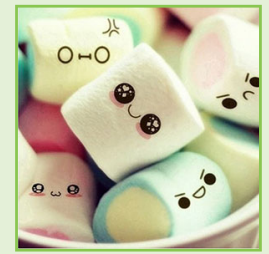

\section{ADITRI, AGE: 12}

My name is Aditri, and I am in 6th grade. Some things I like to do are read and do art. Art is probably my favorite thing to do in my free time. I have been also playing the piano for about 4-5 years. When I grow up I want to be an astrophysicist!

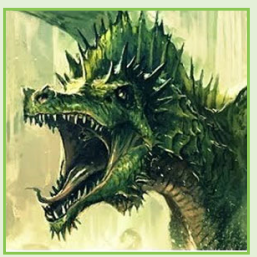

\section{ANSHUL, AGE: 9}

Hello! My name is Anshul and I am a fourth grader in North Wales, Pennsylvania, which is close to Philadelphia. I am very interested in Biology and Entomology. I am an active member of the John Hopkins CTY program, and my favorite hobby is to read. 


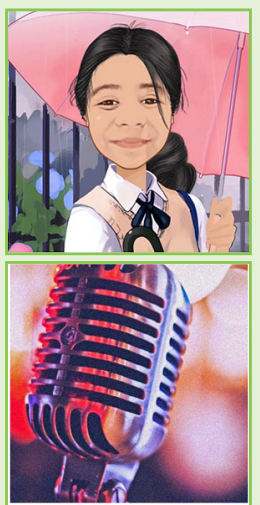

\section{LUVENA, AGE: 11}

$\mathrm{Hi}$, my name is Luvena! I love music, sports, and food. My favorite subjects in school are math and language arts. In my spare time, l enjoy playing piano and reading books with my sister. When I grow up, I would like to be a neurosurgeon.

\section{PRANATEE, AGE: 12}

Hello! I love to bake, especially tarts and pies. In school, my favorite subjects are science, lunch, and recess. I like spending time outdoors and going hiking. I also love going to the beach and have an interest in photography. Watching my favorite TV shows, painting, listening to music, singing, and hanging out with friends are my favorite things to do in my free time. In the future, I would like to either be a scientist, or a singer/songwriter and actress.

\section{AUTHORS}
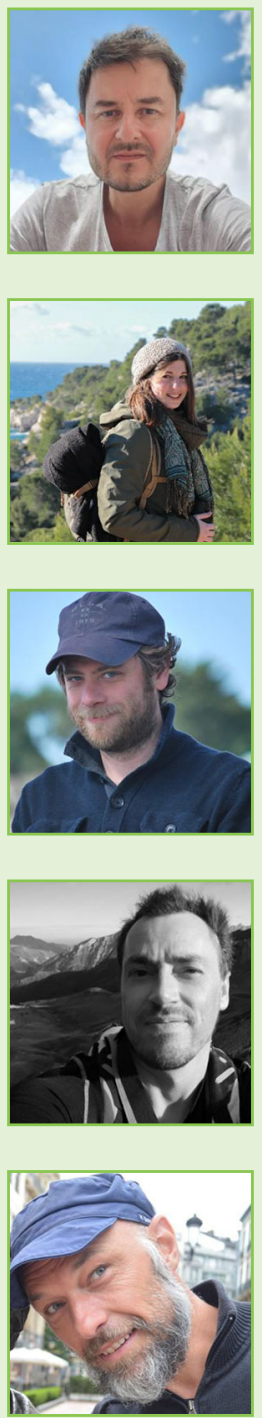

\section{YVAN BETTAREL}

Yvan Bettarel is a marine microbiologist at the French National Research Institute for Sustainable Development (IRD). He has lived and worked in Vietnam and Senegal to study the role that tropical viruses and bacteria play in ocean health. *yvan.bettarel@ird.fr

\section{ELYSE BOUDIN}

Elyse Boudin graduated in Ecology Engineering at the University of Montpellier in 2019. Now, she is involved in several environmental and educational projects in the South of France. These projects combine research in marine and terrestrial ecology, photography, and the creation of environmental education tools.

\section{SÉBASTIEN HALARY}

Sebastien Halary is a microbiologist at the National Museum of Natural History of Paris. He studies bacteria and viruses by deciphering their DNA, in order to understand how all these microbes live together in the environment.

\section{JEAN-CHRISTOPHE AUGUET}

Jean-Christophe Auguet (CNRS Researcher) is an enthusiastic microbial ecologist. His current research focuses on microbes associated with reef animals. Among these microbial assemblages, he is particularly interested by potential pathogenic bacteria that he studies using molecular tools and next generation sequencing.

\section{JEAN PÉRONNIN}

Jean Péronnin is professor of electrical engineering in a vocational School in Issoire (France). He is particularly interested in the health of local rivers and their trout populations. More generally, he is passionate about nature which is a great source of inspiration for his illustrations and paintings. 

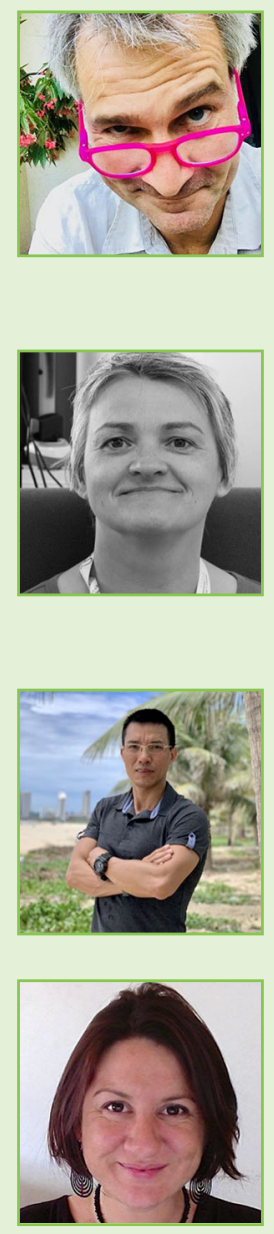

\section{THIERRY BOUVIER}

Thierry Bouvier is a marine microbial ecologist at the MARBEC lab located in Montpellier, France. He started to study the benthic and pelagic bacteria and viruses of the polar, temperate, and tropical oceans. Our research is currently entirely devoted to microbiomes associated with marine animals to understand who they are, their role and their future.

\section{EMMA ROCHELLE-NEWALL}

Emma Rochelle-Newall is an aquatic microbial ecologist at the French National Research Institute for Sustainable Development (IRD). She studies how anthropogenic impacts influence microbial diversity and activity in temperate and tropical ecosystems. She is also looking at how pathogens disseminate and proliferate in aquatic ecosystems, notably in developing countries.

\section{VAN NGOC BUI}

Van Ngoc Bui is a pharmaceutical biologist at the Institute of Biotechnology of Hanoi (Vietnam). His current research focuses on metagenomics and diversity of microbial communities associated to corals.

\section{CHRISTELLE DESNUES}

Christelle Desnues (CNRS Research Director) is passionate about viruses, their ecology and human health. She studies the diversity, dynamics, and evolution of viruses at human-animal-ecosystem interfaces. With her dual research experience in clinical and environmental sciences, she actively makes the bridge between physicians and ecologists, fully in lines with the «One Health-One Medicine» approach, to better understand the interactions between environmental, animal, and human health. 